[Article]

\title{
用三电极体系研究铜在微液滴下的电化学腐蚀
}

\author{
程庆利 张卫华陶 涁 \\ (中国石油化工有限公司青岛安全工程研究院, 山东青岛 266700)
}

\begin{abstract}
摘要: 由于大气腐蚀高阻抗的特征, 传统的参比电极难以用于大气腐蚀研究之中. 为了获取准确的大气腐蚀 电化学信息, 我们需要对传统的参比电极进行修改. 本文在三电极体系中采用修改的参比电极, 通过电化学阻 抗和电化学极化两种方法研究铜在含有 $\left(\mathrm{NH}_{4}\right)_{2} \mathrm{SO}_{4}$ 液滴下的腐蚀行为, 结果表明液滴下铜的平均腐蚀速率随着 液滴体积从 1 到 $20 \mu \mathrm{L}$ 增加而减小; 当液滴高度不超过 $850 \mu \mathrm{m}$ 时, 平均腐蚀速率随着液滴高度的减小却迅速地 增大. 此外, 电化学阻抗和电化学极化得出的腐蚀速率相一致, 这证明修改的参比电极可以用于液滴下的大气 腐蚀研究.
\end{abstract}

关键词: 大气腐蚀; 铜; 电化学阻抗谱; 液滴; 极化曲线; 微电极 中图分类号: O646; TG174.3

\section{Investigation of the Electrochemical Corrosion of Copper under a Micrometric Electrolyte Droplet Using a Three-Electrode System}

\author{
CHENG Qing-Li* ZHANG Wei-Hua TAO Bin \\ (China Petroleum and Chemical Corporation Qingdao Safety Engineering Institute, Qingdao 266700, \\ Shandong Province, P. R. China)
}

\begin{abstract}
Owing to its high impedance, studying atmospheric corrosion using a traditional reference electrode $(\mathrm{RE})$ is difficult. To obtain more accurate information on the electrochemical processes involved in atmospheric corrosion, it is necessary to improve the traditional RE. In this paper, the corrosion behavior of copper under an electrolyte droplet containing $\left(\mathrm{NH}_{4}\right)_{2} \mathrm{SO}_{4}$ was investigated by electrochemical impedance spectroscopy (EIS) and polarization measurements using a three-electrode system with a modified RE. The average corrosion rate increased with decreasing electrolyte volumes (from 1 to $20 \mu \mathrm{L}$ ) and with decreasing heights of the droplet at heights below $850 \mu \mathrm{m}$. The EIS and polarization results were in agreement, thereby demonstrating that the modified RE could be effectively used to study atmospheric corrosion under an electrolyte droplet.
\end{abstract}

Key Words: Atmospheric corrosion; Copper; Electrochemical impedance spectroscopy; Droplet; Polarization curve; Microelectrode

\section{Introduction}

Traditionally, atmospheric corrosion is qualitatively assessed after a timed exposure in an accelerated aging environment. Conventional methods, such as Raman spectroscopy, ${ }^{1} \mathrm{X}$ - ray diffraction (XRD), ${ }^{2,3}$ scanning electron microscopy (SEM), ${ }^{2,4}$ environmental SEM, ${ }^{5}$ X-ray photoelectron spectroscopy (XPS), and atomic force microscopy (AFM), ${ }^{7}$ have been extensively employed to monitor atmospheric corrosion. However, these methods are unable to provide continuous and instantaneous information on atmospheric corrosion. Although gravimetric methods ${ }^{8,9}$ have certain advantages, they require removal of corrosion products by chemical or mechanical treatment, which is cumbersome and also does not provide instantaneous information. Thus, the development of new testing methods that are fast

Received: January 7, 2015; Revised: April 27, 2015; Published on Web: April 27, 2015.

"Corresponding author. Email: chengqingli328@gmail.com; Tel: +86-532-83786955.

The project was supported by the Qingdao People's Livelihood Science and Technology Project, China (11-2-3-56-nsh).

青岛市民生计划项目(11-2-3-56-nsh)资助

(C) Editorial office of Acta Physico-Chimica Sinica 
enough for in situ monitoring of atmospheric corrosion is vital.

Because atmospheric corrosion is mainly an electrochemical process, instantaneous monitoring based on electrochemical measurements has been the subject of numerous studies. ${ }^{10-14}$ In an atmospheric environment, when the temperature drops and the relative humidity $(\mathrm{RH})$ rises at night, moisture in the air may condense to form droplets or a thin liquid layer on solid surfaces. In contrast, during the day, the temperature rises and the $\mathrm{RH}$ decreases, causing the liquid in the droplet to evaporate and the ion concentration to increase. The size (diameter and thickness) of the droplets depends on both dew condensation and rainfall. In particular, competition between oxygen consumption at a metal surface and diffusion at the edge of a droplet results in the establishment of an oxygen concentration gradient. This can lead to the formation of an anodic inner zone and cathodic outer zone. However, the oxygen concentration gradient and cathode-anode separation are also dependent on the droplet size and shape, ${ }^{13}$ such that geometric-driven separation of the anode and cathode occurs in larger drops or on more reactive surfaces. Nazarov and Thierry ${ }^{15}$ applied the Kelvin probe technique to $0.01-0.1 \mathrm{~mol} \cdot \mathrm{L}^{-1} \mathrm{NaCl}$ droplets on pure Al surfaces and found that no cathodic area formed. King et al. ${ }^{16}$ studied AA2024 corrosion under a seawater drop using focused-ion beam (FIB)/SEM. They found that matrix/ particle interfacial attack and grain boundary attack were the predominant attack modes under the droplet.

Owing to the large ohmic drop in atmospheric corrosion environments, it is difficult to monitor atmospheric corrosion using traditional reference electrodes (REs) such as $\mathrm{Ag} / \mathrm{AgCl}$ and saturated calomel electrodes (SCE). Thus, gold, platinum, and chromium-nickel have often been selected as pseudo-REs ${ }^{17,18}$ because these metals do not corrode. However, their electrode potential is influenced by external environmental conditions, ${ }^{19}$ which is problematic because a stable potential is very important for the $\mathrm{RE}$ during electrochemical measurements. To accurately measure the electrode potentials during atmospheric corrosion, several types of miniaturized REs have been developed. ${ }^{20-26}$ Various scanning probe techniques have been proposed to investigate the spatially distributed corrosion kinetics, such as scanning electrochemical microscopy ${ }^{23-26}$ and scanning vibrating electrode technique. ${ }^{27}$ Another approach is to investigate local atmospheric corrosion, which is accomplished by reducing the size of the area investigated by miniaturizing the electrochemical cell. The microelectrodes of small, embedded wires ${ }^{28,29}$ and capillary-based microcell $\mathrm{s}^{30-34}$ provide valuable information because they allow all standard electrochemical measurements to be made. With such techniques, direct evaluation of the local corrosion processes has become easier. However, only a few practical miniaturized REs have been applied to study local atmospheric corrosion.

In the present study, we used a miniaturized RE to monitor the localized corrosion in an electrolyte droplet rather than in a thin film. The miniaturized $\mathrm{RE}$ was a micro- $\mathrm{Ag} / \mathrm{AgCl}$ electrode with a capillary with outer and inner diameters of 0.13 and $0.05 \mathrm{~mm}$, respectively. For the counter electrode (CE), platinum wire of 0.1 $\mathrm{mm}$ diameter was wound several times around the capillary. This experimental setup minimizes the ohmic drop between the RE and working electrode (WE). The miniaturized RE can therefore be used to improve the accuracy of electrochemical corrosion rate measurements. The aim of this study is to demonstrate that a micro-RE can be used to study the local atmospheric corrosion under an electrolyte droplet. The simplicity of this method is one of its main advantages.

\section{Experimental methods}

\subsection{Specimen preparation and chemicals}

Copper (99.9\% (w), Tianjin Yingxiang Steel Co., Ltd., Tianjin, China) was gradually ground to 3000 grit level using emery paper, then polished using diamond paste ( $2-\mu \mathrm{m}$ grain size), and finally degreased with acetone and dried in a cool air flow. A $0.1 \mathrm{~mol} \cdot \mathrm{L}^{-1}$ $\left(\mathrm{NH}_{4}\right)_{2} \mathrm{SO}_{4}$ solution was prepared from analytical grade chemicals (Sinopharm Chemical Reagent Co., Ltd., Shanghai, China) and distilled water. The electrode had an exposure area of $10 \mathrm{~mm} \times 10$ $\mathrm{mm}$ and electrolyte droplet was produced by placing a desired volume $(1-20 \mu \mathrm{L})$ of the solution onto the metal surface using a microsyringe. The following chemical reagents were analytical grade chemicals (Sinopharm Chemical Reagent Co., Ltd., Shanghai, China).

\subsection{Experimental design}

The micro- $\mathrm{Ag} / \mathrm{AgCl}$ electrode is shown in Fig.1. The salt bridge in the capillary tube tip was made by sucking a hot solution composed of $2 \%$ agar and $3.33 \mathrm{~mol} \cdot \mathrm{L}^{-1} \mathrm{KCl}$. The capillary was then cooled to room temperature to allow the agar electrolyte to solidify. ${ }^{35}$ The internal electrolyte solution contained $3.33 \mathrm{~mol} \cdot \mathrm{L}^{-1}$ $\mathrm{K}_{2} \mathrm{SO}_{4}$ and $\mathrm{AgCl}$. A capillary tube was used as the body of the micro-RE. The micro-Ag/AgCl electrode was constructed by incorporating an agar salt bridge into the microcapillary tip and by incorporating an $\mathrm{Ag} / \mathrm{AgCl}$ electrode into the glass tube of the capillary. $\mathrm{AgCl}$ was deposited electrochemically on a $0.5-\mathrm{mm}$ diameter $\mathrm{Ag}$ wire in $0.1 \mathrm{~mol} \cdot \mathrm{L}^{-1} \mathrm{KCl}$ solution for 3 min with an electric current of $2 \mathrm{~mA} \cdot \mathrm{cm}^{-2}$. The bare portion of the $\mathrm{Ag}$ wire without any $\mathrm{AgCl}$ was covered with silica gel. Subsequently, the $\mathrm{Ag} / \mathrm{AgCl}$ electrode was inserted into the electrolyte in the capillary glass tube with a protective cap. For the counter electrode, platinum wire of 0.1-mm diameter was wound several times around

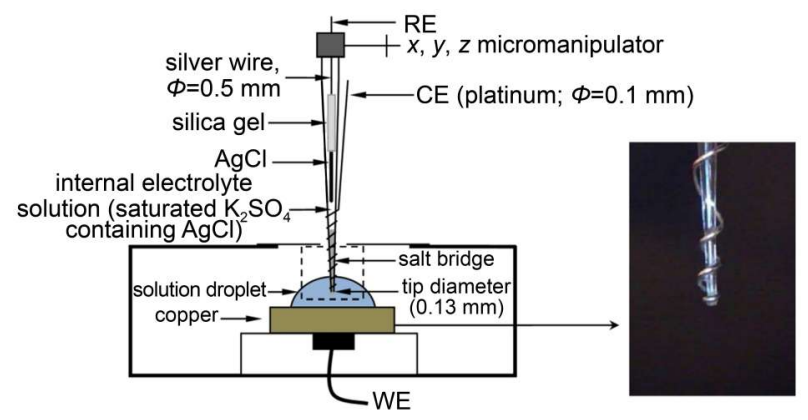

Fig.1 Schematic representation of the electrochemical experimental setup for copper corrosion under an electrolyte droplet containing $\left(\mathrm{NH}_{4}\right)_{2} \mathrm{SO}_{4}$ 
the capillary tube tip. The capillary tube was fixed to an $x, y, z$ micromanipulator, which allowed precise positioning of the electrode ensemble within the droplet. To reduce contamination from the RE through ion leakage, the RE was removed from the droplet after each electrochemical measurement. The experimental setup is shown in Fig.1.

\subsection{Instrumentation}

All electrochemical measurements were conducted using a CHI660D electrochemical workstation (Shanghai Chenhua Device Company, China). Electrochemical impedance spectroscopy (EIS) measurements were conducted in the frequency range from 100 $\mathrm{kHz}$ to $0.1 \mathrm{~Hz}$ at an open circuit potential (OCP) with a potential perturbation of $\pm 5 \mathrm{mV}$. Polarization curves were measured from -250 to $+100 \mathrm{mV}(v s \mathrm{OCP})$ at a scan rate of $5 \mathrm{mV} \cdot \mathrm{s}^{-1}$. The dimensions of the droplets were carefully measured using a digital microscope. For reproducibility, three samples were used in each experiment and the average values are reported.

\section{Results and discussion}

\subsection{Determination of the droplet size}

Electrolyte droplets with varying volumes were placed on the copper surface using microsyringes. The largest droplet had a diameter of $(4.72 \pm 0.08) \mathrm{mm}$ and a height of $(2.24 \pm 0.12) \mathrm{mm}$. According to Ref.34, this procedure allows accurate deposition of droplet volumes down to $0.3 \mu \mathrm{L}$. However, in the present study, the electrochemical measurements of the average corrosion rates could not be determined with sufficient precision when the droplet volume was smaller than $1 \mu \mathrm{L}$. Thus, a droplet volume range of $1-20 \mu \mathrm{L}$ was chosen.

\subsection{EIS measurements}

Corrosion occurs under a microdroplet as a result of the oxygen concentration cell. The localized zone of the electrochemical reaction under the electrolyte droplet can be divided into a bulk zone and a three-phase boundary (TPB) zone. The term TPB is frequently used in the study of solid-oxide fuel cells. ${ }^{36,37}$ The thickness of the static diffusion layer is generally agreed to be about $100 \mu \mathrm{m} .{ }^{38}$ If the electrolyte thickness $(\delta)$ exceeds $100 \mu \mathrm{m}$ in the bulk zone, the diffusion rate of oxygen is similar to that in the solution; that is, independent of $\delta$. In the TPB zone where $\delta$ ranges from 0 to $100 \mu \mathrm{m}$, the diffusion rate of oxygen first increases and then decreases with a reduction in $\delta ;{ }^{38,39}$ however, the average rate is still higher in the TPB zone than that in the bulk zone. This reveals the importance of the TPB zone in cathodic oxygen reduction. Moreover, it was shown that the cathodic limiting current density and corrosion current density increased linearly with increasing TPB length per unit area $(g)$. The parameter $g$ is defined as $g=2 / r$, where $r$ is the radius of the droplet $(\mathrm{cm})$. Thus, the average corrosion rate decreases with increasing $r$ when the contact angle of the droplet is constant. In the present study, the variation in contact angle (from $84.4^{\circ}$ to $88.8^{\circ}$ ) is considered negligible. Consequently, the average corrosion rate is expected to decrease with increasing droplet volume.

The Nyquist plot of a $20-\mu \mathrm{L}$ droplet containing $\left(\mathrm{NH}_{4}\right)_{2} \mathrm{SO}_{4}$ is shown in Fig.2(a). The straight line in the low-frequency region confirms that the reaction is diffusion controlled. Consequently, kinetic factors are able to be directly deduced from the impedance spectrum. Usually, the modulus value $\left(R_{\mathrm{p}}\right)$ in the low-frequency region is inversely proportional to the corrosion rate. ${ }^{40}$ Nishikata and Ichihara ${ }^{11}$ used $R_{\mathrm{p}}$ to evaluate the corrosion rate in a real atmospheric environment. As shown in Fig.2(b), the reciprocal of $R_{\mathrm{p}}\left(1 / R_{\mathrm{p}}\right)$ can be deduced accurately resulting in an average corrosion rate of $0.0012 \Omega^{-1} \cdot \mathrm{cm}^{-2}$ in the low-frequency region $(0.01$ $\mathrm{Hz}$ ). However, a long time was required to measure the impedance modulus values at $0.01 \mathrm{~Hz}$, which is not ideal because the corrosion rate is time dependent. Thus, we chose $R_{\mathrm{p}}$ values at $0.1 \mathrm{~Hz}$ rather than at $0.01 \mathrm{~Hz}$ to circumvent this problem. The Bodemagnitude plot (Fig.2(b)) shows that the error in $1 / R_{\mathrm{p}}$ at $0.1 \mathrm{~Hz}$ was small; the average corrosion rate determined at $0.1 \mathrm{~Hz}$ was $0.0017 \Omega^{-1} \cdot \mathrm{cm}^{-2}$ with an error of only $0.0003 \Omega^{-1} \cdot \mathrm{cm}^{-2}$. Therefore, EIS analysis was performed within the frequency range of 100 $\mathrm{kHz}$ to $0.1 \mathrm{~Hz}$. It has been reported that the average corrosion rate is influenced by the thickness of the electrolyte film. ${ }^{2}$ In this study, as shown in Fig.3, when the thickness of the electrolyte droplet was greater than $850 \mu \mathrm{m}$, the corrosion process was similar to that in bulk solution, with only a slight decrease in average corrosion rate with increasing thickness. When the electrolyte thickness was between 220 and $850 \mu \mathrm{m}$, the oxygen diffusion rate and subsequently average corrosion rate increased with decreasing thickness. This result is similar to that in Ref.34. Thus, thinner elec-
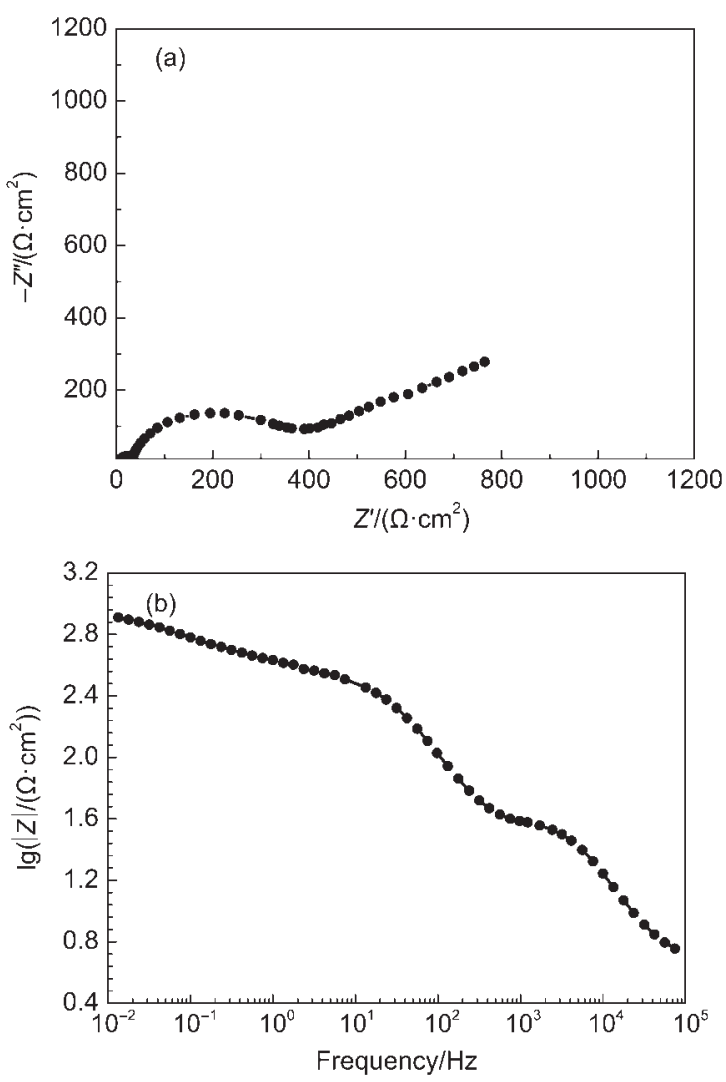

Fig.2 (a) Nyquist plot and (b) Bode-magnitude plot for copper corrosion under a $20-\mu \mathrm{L}$ electrolyte droplet 

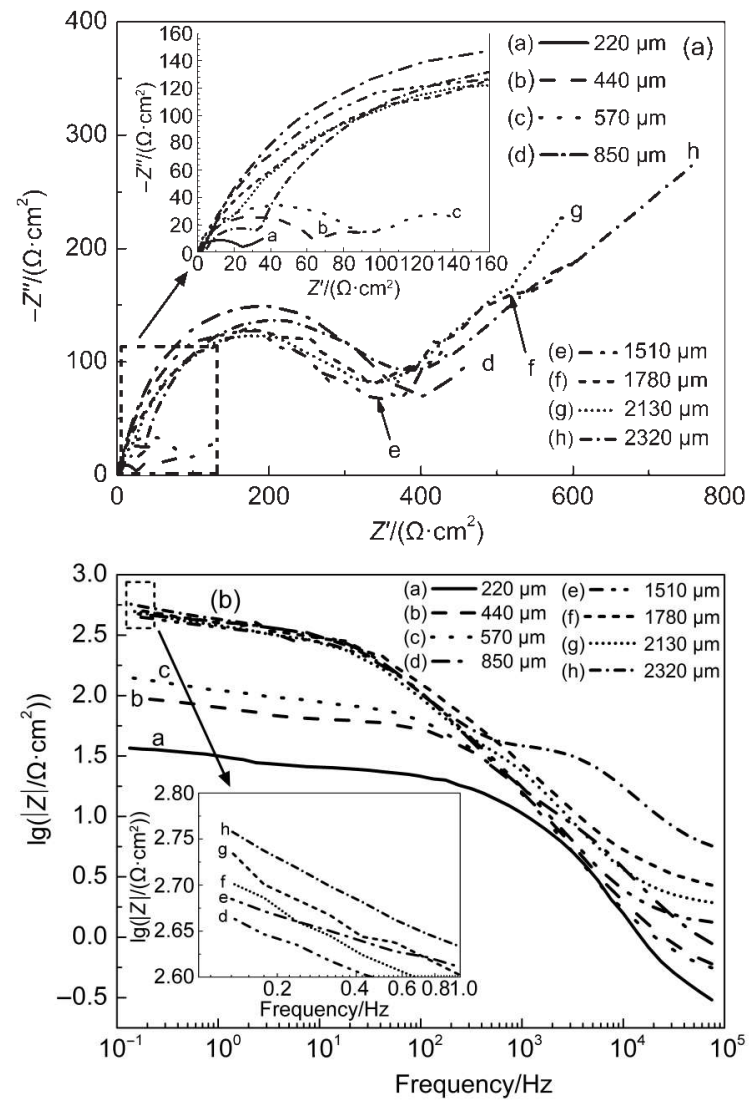

Fig.3 (a) Nyquist plot and (b) Bode-magnitude plot for copper corrosion under electrolyte droplets of different heights

trolyte droplets (i.e., $<850 \mu \mathrm{m}$ ) permit gases to diffuse faster through the surface, resulting in increased average corrosion rates. As previously mentioned, volumes smaller than $1 \mu \mathrm{L}$ were not deposited. Accordingly, droplet heights smaller than $850 \mu \mathrm{m}$ were achieved by allowing $1-\mu \mathrm{L}$ droplets to evaporate in nitrogen atmosphere. Fig. 4 shows the height of a $1-\mu \mathrm{L}$ droplet as a function of evaporation time. The solute concentration in the droplet increases as the solution evaporates, which may potentially affect the corrosion rate. However, the corrosion rate is dominated by oxygen reduction in the early stages of atmospheric corrosion. ${ }^{2}$

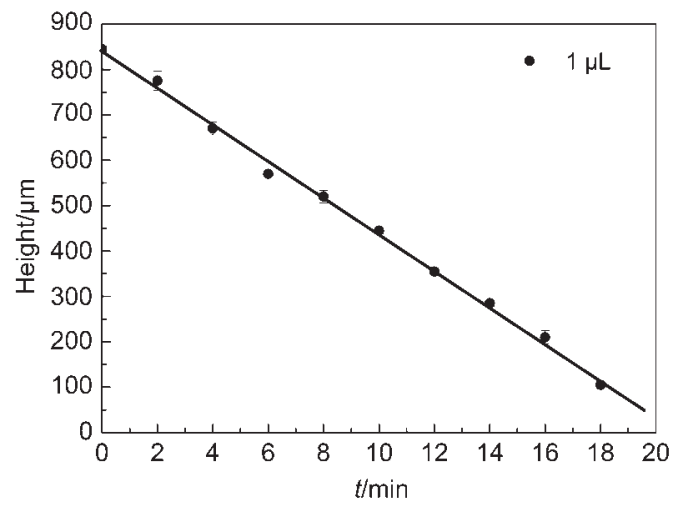

Fig.4 Change in the height of an electrolyte droplet (initial volume: $1 \mu \mathrm{L}$ ) with time through evaporation at $55 \%$ relative humidity $(\mathrm{RH})$
Thus, the effect of a change in electrolyte concentration can be expected to be negligible. These findings indicate that measurements in an electrolytic droplet using microelectrodes enable one to distinguish the different corrosion mechanisms at work.

\subsection{Polarization curves}

The extent of distortion of the potentiodynamic polarization curve depends on the scan rate. For most corrosion systems, disturbance of the charging current is minimized by adopting a low scan rate (ca $0.1 \mathrm{mV} \cdot \mathrm{s}^{-1}$ ), and distortion of the potentiodynamic polarization curve is avoided. A slower scanning rate means that steady-state conditions are more closely approached. However, a slower scanning rate also greatly extends the polarization time, which results in the polarization potential more readily inducing irreversible changes in the interfacial structure. This increases the difficulty of accurately measuring the polarization curves. In the present study, the corrosion rate is sensitively affected by the contact time with the electrolyte droplet. Thus, we adopted a faster scan rate $\left(5 \mathrm{mV} \cdot \mathrm{s}^{-1}\right)$ to obtain more accurate corrosion rates without deviating appreciably from steady-state conditions. Potentiostatic polarization curves are shown in Fig.5. It can be seen that the droplet size influenced the form of the cathodic polarization curve. Moreover, a reduced droplet height accelerates the cathodic reaction and increases the average corrosion rate, as shown in Fig.6. This result is in accordance with the EIS results.

According to Ref.41, the corrosion rate is constant at values of $\delta>1 \mathrm{~mm}$. However, as previously mentioned, when the droplet height exceeds $850 \mu \mathrm{m}$, the average corrosion rate is not constant but slightly decreases with increasing volume. This phenomenon can be explained as follows. A droplet influences the localized corrosion behavior of metals in gas-liquid-solid multiphase corrosion systems. Although an increased droplet volume increases the length of the TPB region, the $g$ values decrease. As a result, the average corrosion rate under the electrolyte droplet decreases with increasing droplet volume in the range of $1-20 \mu \mathrm{L}$.

\subsection{Corrosion rate determination during droplet evaporation}

The diameter of the droplet remains constant with time during

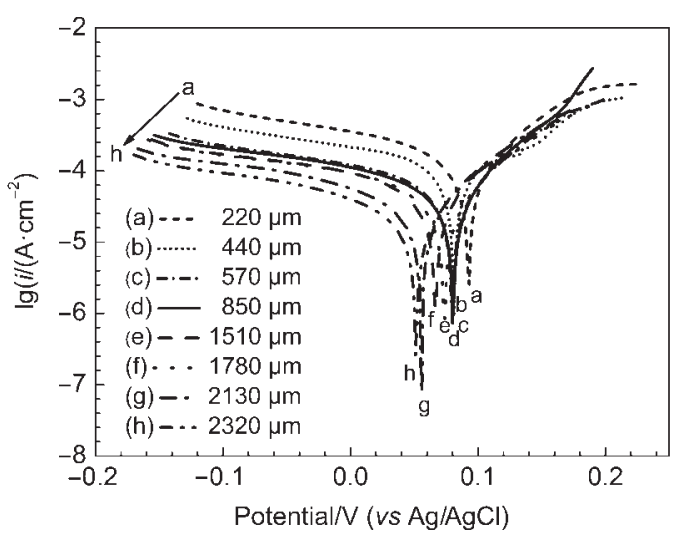

Fig.5 Polarization curves for copper corrosion under electrolyte droplets of different heights 


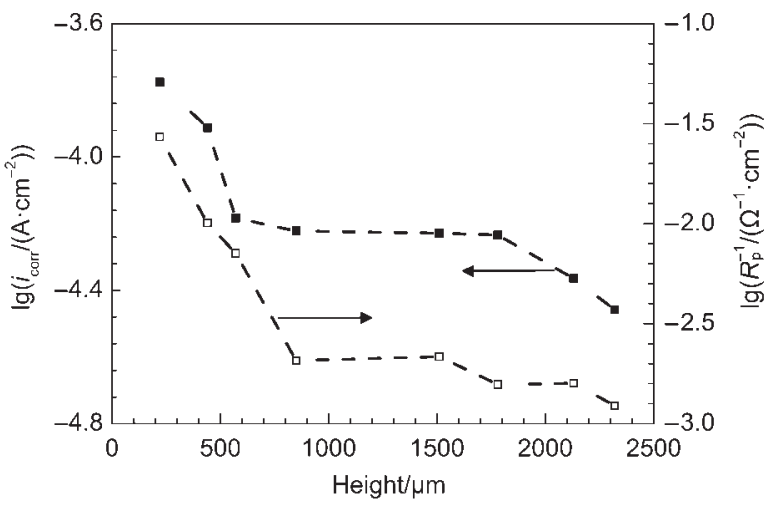

Fig.6 Variation of the average corrosion rate of copper under the electrolyte droplets of different heights
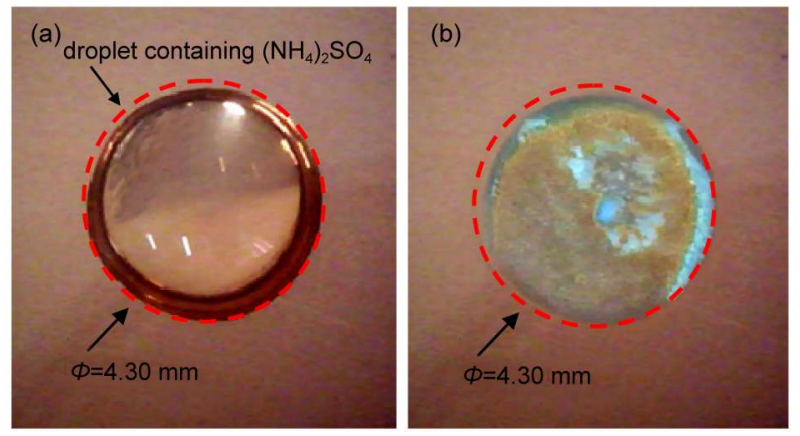

Fig.7 Image of a droplet (initial volume: $20 \mu \mathrm{L}$ ) containing $\left(\mathrm{NH}_{4}\right)_{2} \mathrm{SO}_{4}$ at (a) 0 min and (b) after evaporation for $160 \mathrm{~min}$ at $55 \% \mathrm{RH}$
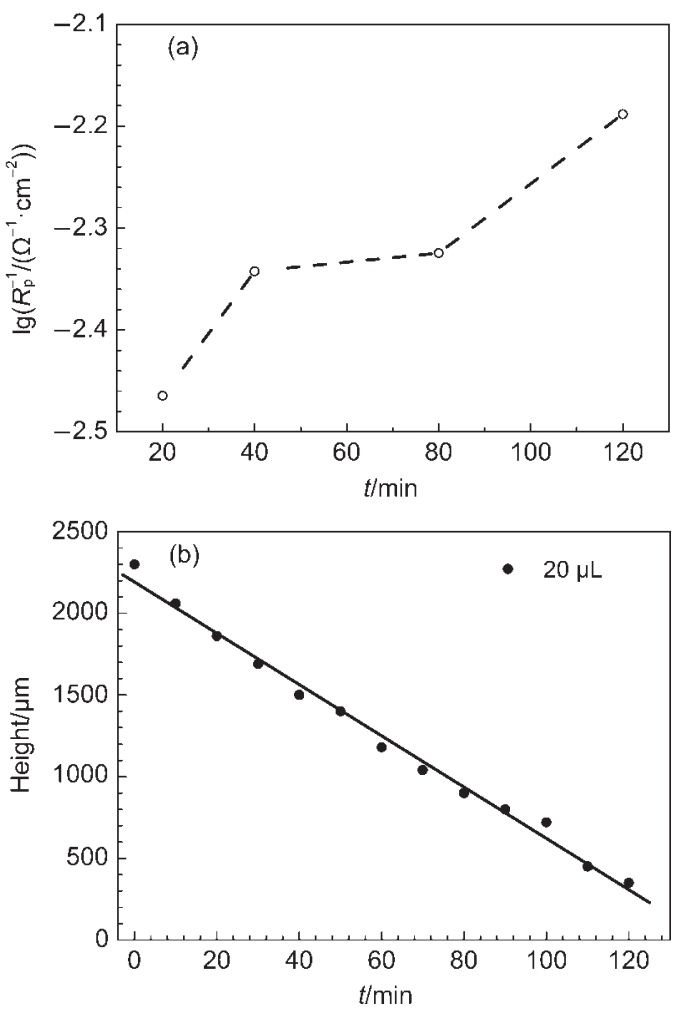

Fig.8 Variation of the average corrosion rate (a) and droplet height (b) with evaporation time at $55 \%$ RH for an initial droplet volume of $20 \mu \mathrm{L}$ evaporation at 55\% RH as shown in Fig.7. Thus, no secondary spread of the droplets occurs during electrochemical measurements in the present study. In Fig.8(a), the corrosion rate can be seen to increase with evaporation time. In Fig.8(b), the droplet height can be seen to decrease with time, which is beneficial for oxygen diffusion and promotes oxygen reduction. In addition, the electrolyte concentration increases during evaporation, which intensifies the attack of aggressive ions and consequently increases the anodic dissolution rate. Accordingly, the average corrosion rate under the electrolyte droplet increases with evaporation time.

\section{Conclusions}

The atmospheric corrosion behavior of copper under an electrolyte droplet containing $\left(\mathrm{NH}_{4}\right)_{2} \mathrm{SO}_{4}$ was investigated using a modified three-electrode system. EIS and polarization measurements allowed quantification of the change in corrosion rate when the thickness of the droplet was changed; the EIS and polarization results were in good agreement. The average corrosion rate slightly decreased when the electrolyte volume was increased from 1 to $20 \mu \mathrm{L}$; this was attributed to the lower $g$ values at larger electrolyte volumes. Below $850 \mu \mathrm{m}$, an increase in the average corrosion rate was observed with decreasing electrolyte thickness. These results demonstrate that the modified three-electrode system can be accurately used to investigate local atmospheric corrosion on different surfaces.

\section{References}

(1) Azmat, N. S.; Ralston, K. D.; Muddle, B. S.; Cole, I. S. Corrosion Sci. 2011, 53, 1604. doi: 10.1016/j.corsci.2011.01.044

(2) Liao, X. N.; Cao, F. H.; Zheng, L. Y.; Liu, W. J.; Chen, A.; Zhang, J. Q.; Cao, C. N. Corrosion Sci. 2011, 53, 3289.

(3) Su, Y. Y.; Shemenski, R. M. Surf. Interface Anal. 2008, 40, 1183. doi: 10.1002/sia.v40:8

(4) Hastuty, S.; Nishikata, A.; Tsuru, T. Corrosion Sci. 2010, 52, 2035.

(5) Chen, J.; Wang, J.; Han, E.; Ke, W. Corrosion Sci. 2007, 49, 1634.

(6) Tran, T.; Fiaud, C.; Sutter, E.; Villanova, A. Corrosion Sci. 2003, 45, 2802.

(7) Wadsak, M.; Aastrup, T.; Wallinder, I. O.; Leygraf, C.; Schreiner, M. Corrosion Sci. 2002, 44, 791.

(8) Chen, Y. Y.; Tzeng, H. J.; Wei, L. I.; Shih, H. C. Mater. Sci. Eng. A 2005, 47, 398.

(9) Sun, F. J.; Wang, J. Acta Phys. -Chim. Sin. 2012, 28, 615. [孙 凤娟, 王 佳. 物理化学学报, 2012, 28, 615.] doi: 10.3866/ PKU.WHXB201201101

(10) Wang, J.; Tsuru, T. J. Chin. Soc. Corros. Prot. 1995, 15, 180. [王 佳, 水流彻. 中国腐蚀与防护学报, 1995, 15, 180.]

(11) Nishikata, A.; Ichihara, Y. Corrosion Sci. 1995, 37, 897. doi: 10.1016/0010-938X(95)00002-2

(12) El-Mahdy, G. A.; Nishikata, A.; Tsuru, T. Corrosion Sci. 2000, 
$42,1509$.

(13) Venkatraman, M.; Cole, I. S.; Gunasegaram, D. R.; Emmanuel, B. Mater. Sci. Forum. 2010, 654-656, 1650.

(14) Cheng, Q. L.; Song, S. H.; Song, L. Y.; Hou, B. R. J. Electrochem. Soc. 2013, 160, C380.

(15) Nazarov, A.; Thierry, D. Electrochim. Acta 2004, 49, 2717. doi: 10.1016/j.electacta.2004.01.066

(16) King, P. C.; Cole, I. S.; Corrigan, P. A.; Hughes, A. E.; Muster, T. H. Corrosion Sci. 2011, 53, 1086.

(17) Williams, G.; McMurray, H. N. J. Electrochem. Soc. 2001, 148, B377.

(18) Williams, G.; McMurray, H. N. Electrochem. Commun. 2003, 5, 871. doi: 10.1016/j.elecom.2003.08.008

(19) Ehahoun, H.; Stratmann, M. Electrochim. Acta 2005, 50, 2667. doi: 10.1016/j.electacta.2004.11.011

(20) Bakker, E.; Diaz, M. T. Anal. Chem. 2002, 74, 2781. doi: $10.1021 / \mathrm{ac} 0202278$

(21) Chen, S.; Kucernak, A. Electrochem. Commun. 2002, 4, 80. doi: 10.1016/S1388-2481(01)00278-8

(22) Nakajima, K.; Yamagiwa, T.; Hirano, A.; Sugawara, M. Anal. Sci. 2003, 19, 55.

(23) Fushimi, K.; Seo, M. Electrochim. Acta 2001, 47, 121. doi: 10.1016/S0013-4686(01)00557-6

(24) Katemann, B. B.; Inchauspe, C. G.; Castro, P. A.; Schultze, A.; Calvo, E. J.; Schuhmann, W. Electrochim. Acta 2003, 48, 1115. doi: 10.1016/S0013-4686(02)00822-8

(25) Gabrielli, C.; Joiret, S.; Keddam, M.; Perrot, H.; Portail, N.; Rousseau, P.; Vivier, V. Electrochim. Acta 2007, 52, 7706. doi: 10.1016/j.electacta.2007.03.008

(26) Keddam, M.; Portail, N.; Trinh, D.; Vivier, V. ChemPhysChem 2009, 10, 3175 .
(27) Isaacs, H. S. J. Electrochem. Soc. 1991, 138, 722. doi: 10.1149/ 1.2085665

(28) Sanchez, M.; Gamby, J.; Perrot, H.; Rose, D.; Vivier, V. Electrochem. Commun. 2010, 12, 1230. doi: 10.1016/j. elecom.2010.06.026

(29) Stulik, K.; Amatore, C.; Holub, K.; Marecek, V.; Kutner, W. Pure. Appl. Chem. 2000, 72, 1483.

(30) Vogel, A.; Schultze, J. W. Electrochim. Acta 1999, 44, 3751. doi: 10.1016/S0013-4686(99)00080-8

(31) Vignal, V.; Krawiec, H.; Heintz, O.; Oltra, R. Electrochim. Acta 2007, 52, 4994. doi: 10.1016/j.electacta.2007.01.079

(32) Murer, N.; Oltra, R.; Vuillemin, B.; Néel, O. Corrosion Sci. 2010, 52,130 .

(33) Krawiec, H.; Vignal, V.; Akid, R. Electrochim. Acta 2008, 54, 5252.

(34) Dubuisson, E.; Lavie, P.; Dalard, F.; Caire, J. P.; Szunerits, S. Corrosion Sci. 2007, 49, 910.

(35) Kitade, T.; Kitamura, K.; Takegami, S.; Miyata, Y. Japn. Soc. Anal. Chem. 2005, 21, 907.

(36) Nam, J.; Jeon, D. Electrochim. Acta 2006, 51, 3446. doi: 10.1016/j.electacta.2005.09.041

(37) Ni, M.; Leung, M. K. H.; Leung, D. Y. C. J. Power Sources 2007, 168, 369. doi: 10.1016/j.jpowsour.2007.03.005

(38) Tsuru, T.; Nishikata, A.; Wang, J. Mater. Sci. Eng. A 1995, 198, 161. doi: 10.1016/0921-5093(95)80071-2

(39) Ga, J. J.; Ga, J. W.; Lua, Y. H.; Hua, J. Z. Electrochim. Acta 2009, 54, 1426. doi: 10.1016/j.electacta.2008.09.017

(40) Nishikata, A.; Ichihara, Y.; Hayashi, Y.; Tsuru, T. J. Electrochem. Soc. 1997, 144, 1244. doi: 10.1149/1.1837578

(41) Huang, H. L.; Dong, Z. H.; Chen, Z. Y.; Guo, X. P. Corrosion Sci. 2011, 53, 1230 . 